\title{
Combining ability and Heterosis Analysis for Yield and Contributing Traits in Local Germplasm of Yellow Sarson (Brassica rapa var. Yellow Sarson Prain)
}

\author{
Sanchika Snehi*, Ram Bhajan, Usha Pant and N.K. Singh \\ Department of Genetics and Plant Breeding, GBPUA\&T, \\ Pantnagar, U.S Nagar, Uttarakhand, India \\ *Corresponding author
}

\section{A B S T R A C T}

\section{Keywords}

Brassica rapa var. yellow sarson, LinexTester analysis, $\sigma^{2} \sigma_{\text {sca, }}^{2}$ gca, Heterobeltiosis, Economic heterosis

Article Info

Accepted:

10 June 2019 Available Online: 10 July 2019
The present study aimed to estimate the general and specific combining ability variances and their effects, and extent of heterobeltiosis and economic heterosis for different quantitative characters in yellow sarson. Line $\times$ Tester analysis including 11 local germplasm lines and four testers illustrated the preponderance $\sigma^{\sigma_{\text {sca }}}$ over ${ }^{2}$ gca for all the traits studied. Based on desirable GCA effects, PYSC-11-3, PYSC-11-36, PYSC-11-44 and PYSC-11-46 among lines and B-9 among testers were identified as promising donars for seed yield. High GCA for seed yield was associated with high seeds per siliqua, siliqaua density, siliqua on main raceme, primary branches per plant and plant height. The parental lines PYSC-13-1, PYSC-12-1 and B-9 emerged as promising donor for oil content. B-9 was only parent possessing high GCA parent for seed yield as well as oil content conjugated with key component traits. Based on desirable SCA effects and high heterotic response for seed yield, PYSC-11-46 $\times$ B-9, PYSC-11-44 $\times$ PPS-1 and PYSC-11$36 \times$ YSH-401 for seed yield and PYSC-12-1 $\times$ B-9 and PYSC-12-1 $\times$ PPS- 1 for oil content were marked as most promising crosses and recommended for further exploitation in the breeding programme. The above findings gesture towards the use of heterosis breeding as the key method for exploiting the available genetic variability in the pool of material studied.

\section{Introduction}

The oleiferous Brassica species, commonly known as rapeseed-mustard, are one of the economically important agricultural commodities. In India, rapeseed-mustard are second largest oilseed crop after soybean and contribute about 30 per cent of the total oilseeds produced in the country (IIOR/DOR, Hyderabad, and A.P.) as well as $15 \%$ to the world's contribution. Among rapeseedmustard, B. rapa var. toria, brown sarson and yellow sarson are endowed with higher oil quality and early maturity (around 100 days) as compared to Indian mustard (130-150 days). Amongst the three sub-species of $B$. rapa, yellow sarson occupies authoritative position due to the presence of high oil content (up to $46 \%$ ), high seed yield and early maturity. Moreover its yellow seed coat 
colour imparts light coloured clearer oil which is preferred over brown seeded toria and brown sarson. The yellow sarson being autogamous in nature has an edge over outbreeding toria types under adverse weather situation such as foggy and cloudy conditions. In spite of all these merits, the yellow sarson varieties, in general, suffer from low productivity and deserves greater attention in varietal improvement. Appreciably high level of heterosis in $B$. rapa ( 25 to 110 per cent) generated interest of plant breeders to harness hybrid vigour. This study presents the results of combining ability and heterosis in local germplasm lines under tarai conditions (Pantnagar) of Uttarakhand.

\section{Materials and Methods}

The experimental materials for the present investigation consisted of 11 local germplasm lines collected from Uttarakhand hills, Eastern UP and Bihar viz. PYSC-11-3, PYSC11-31, PYSC-11-36, PYSC-11-44, PYSC-1146, PYSC-13-1, PYSC-13-12, PYSC-13-14-2, IC-338742, NDYS-117, PYSC-12-1 used as females and 4 released popular varieties used as males viz. YSH-401, PPS-1, B-9, Pant Sweta (Table 1). All the crosses were produced by hand emasculation and pollination to avoid chances of mixing. The parents were crossed in line $\times$ tester mating design. A set of experimental material consisting of 11 lines, 4 testers and $44 \mathrm{~F}_{1}$ were evaluated in a randomized block design with three replications in single environments during rabi season of 2016-17 for 12 traits including days to 50 per cent flowering, days to maturity, plant height $(\mathrm{cm})$, number of primary branches per plant, number of siliquae on main raceme, length of main raceme $(\mathrm{cm})$, siliqua density, siliqua length (cm), seeds per siliqua, 1000-seed weight (g), seed yield per plant (g), oil content (\%). Oil content was determined from NIR facility available at DRMR, Bharatpur. Each plot in a replication comprised of a single row of $3 \mathrm{~m}$ length spaced at $30 \mathrm{~cm}$ and plant to plant distance of $10 \mathrm{~cm}$ was maintained by thinning. In order to debar border effect, experimental plots were encircled by one row of B-9. Standard variety Pant Sweta was treated as check in the experiments. Recommended package of practise was followed equally for all the entries in order to raise a good crop. The gca and sca effects in combining ability analysis were estimated using model as described by Kempthorne (1957) and heterobeltiosis, and standard heterosis (Pant Sweta), was calculated according to method suggested by Hayes, Immer et al.,(1955)

\section{Results and Discussion}

A combined ANOVA presenting mean squares for all traits studied are presented in Table 2. The combined ANOVA depicted highly significant $(\mathrm{p} \leq 0.01)$ difference among treatments and their sub-source of variation (parents, crosses and parents vs. crosses) for all traits studied barring 1000-seed weight and oil content for later. The results revealed the existence of substantial variability among parents, crosses as well as parents vs. crosses for most of the traits. Similar results were reported by Chaudhari, Patel et al., (2015), Tomar, Singh et al., (2018)

\section{Line $\times$ Tester analysis}

The test of significance of variances due to lines and tester against their interaction component (line $\times$ tester) exhibited that differences among lines were significant for six characters namely plant height, number of primary branches, siliqua density, siliqua length, number of seeds/siliqua and oil content. On the other side differences among tester were significant for all traits except number of primary branches, seed yield/plant and oil content and the interaction component (line $\times$ tester) was highly significant for all 
the traits studied (Table 2). Sachan, Singh et al., (2004) also reported highly significant difference for interaction component wrt. all traits except oil content. These result suggest the relevance of specific combining ability indicating greater role of non-additive genetic component in the inheritance of these traits. Tomar, Singh et al., (2018).

\section{General combining ability effects}

General combining ability reflect genetic worth of the parental line for use in combination breeding. The line with high GCA effect for the character are expected to be more useful donors than those with poor GCA. GCA effects of all the parental lines and tester are summarized in Table 3. Based on the GCA effects, parents used in the study were ranked $(\mathrm{G}=$ good general combiner, $\mathrm{A}=$ average general combiner and $\mathrm{P}=$ poor general combiner) given to each parents for various characters. The results clearly pointed that none of the line/ tester was good general combiner for all the characters. Each of the parent emanated as good general combiner for variable number of traits. Among testers, B-9 was a good donor parent for seven traits, PPS1 for six, YSH-401 for five and Pant Sweta for three. Similarly among lines PYSC-11-36 and PYSC-11-44 showed high GCA for six characters each; PYSC-13-14-2 for five; PYSC-11-3, PYSC-11-46 and NDYS-117 for four; PYSC-13-1 and PYSC-13-12 for three and IC-338742 for two characters. The high GCA of PYSC-11-36 for seed yield was associated with high GCA for siliqua density, siliqua on main raceme, primary branches per plant, length of main raceme and days to maturity. High GCA for seed yield in case of PYSC-11-44 was associated with high seeds per siliqua, siliqua density, siliqua on main raceme, primary branches per plant and plant height, high GCA effect of PYSC-11-3 for seed yield was contemplation of positive GCA effect for days to maturity, siliqua length and 1000-seed weight (Table 4). This tend to infer that high GCA status for seed yield in different lines differed considerably in the constellation of component traits with high GCA. These findings were in agreement with the results reported earlier by Dhillon, Labana et al., (1990), Gupta, Chaudhary et al., (2010). The lines PYSC-13-1 and PYSC12-1 and tester B-9 emerged as promising donor for oil content. Of these, only B-9 was identified as promising donor parent for seed yield as well as oil content conjugated with key component traits.

\section{Specific combining ability effects}

The success of any crop improvement programme via genetic recombination is fundamentally driven by selection of superior combinations and their subsequent handling by application of suitable breeding procedures. That is why SCA analysis becomes intrinsic. A relook of the characterwise presentation of specific combining ability effects (SCA), (Table 5) showed that out of 44 crosses, 7,13 and 16 crosses each manifested significant SCA effects in desirable direction for days to $50 \%$ flowering, days to maturity and plant height respectively. Similarly, four crosses for primary branches per plant, eight for length of main raceme, 12 for Siliqua on main raceme, 11 each for siliqua density, siliqua length and seed yield, 19 for seeds per siliqua, 15 for 1000-seed weight and seven for oil content manifested significant positive SCA effects. Length of main raceme and primary branches per plant constitute the major sink portion in the yellow sarson. Apparently the frequency of crosses with desirable SCA effects was low, but the magnitude was of high order. Similarly limited number of crosses displayed desirable interaction for oil content and days to $50 \%$ flowering. A reference to the SCA effects of seed yield per plant showed that 25 per cent of the crosses exhibited desirable SCA 
effects. There appeared some correspondence between the magnitude of SCA effect and perse performance of the promising crosses. Further there was no consistency in the GCA status of the parents involved in the crosses having significant SCA effects. The superior crosses for yield as well as oil content were identified and are having $\mathrm{H} \times \mathrm{H}, \mathrm{H} \times \mathrm{L}$ or $\mathrm{L} \times \mathrm{L}$ GCA parents. These results indicate the operation of additive $x$ additive, additive $\times$ dominance, dominancex dominance gene interactions for expression of these traits. Operation of later type of interaction was more prevalent for oil content as five out of the seven promising crosses combine low $\times$ low GCA parents.

\section{GCA and SCA variance components}

Estimates of variance components and ratio for GCA to SCA effects are presented in Table 6 . The estimates of $\sigma^{2}$ sca were found to be higher than $\sigma^{2}$ gca for all the traits. The estimates of $\sigma^{2}$ sca were found to be higher than $\sigma^{2}$ gca for all the traits studied. Tripathi, Bhajan et al.,(2005) also reported prevalence of $\sigma^{2}$ sca siliqua/plant, test weight, seed yield/plant and oil content. The estimates of $\sigma^{2} \mathrm{D}$ and ${ }^{\sigma^{2}} \mathrm{H}$ for different characters showed that the relative magnitude for later was greater than former for all the traits studied. Further the estimate of average degree of dominance was in the range of over dominance for all the traits studied (Table 6), which further substantiate the prevalence of non-additive genetic component.

Similar findings have been reported earlier by Tripathi, Bhajan et al.,(2005), Dar, Wani et al., (2011), Rahman, Chowdhury et al., (2011), Chaudhari, Patel et al.,(2015) and Tomar, Singh et al.,(2018). Sachan, Singh et al., (2004) reported days to maturity, number of primary branches, number of secondary branches, number of siliqua on main raceme seed yield per plant and oil content are goverened by non-additive gene action while for days to flower and 1000-seed weight additive gene action plays key role. Consideration of the estimates of heritability in narrow sense will further assist in unveiling the underlying gene effects. Following the classification of $\left(\mathrm{h}^{2}\right)$ by Robinson (1966) into three categories, viz., high $(>30 \%)$, medium $(10-30 \%)$ and low $(<10 \%)$ heritability showed that it ranged from medium to low for all the traits studied (Table 6). Low estimate of $h^{2}$ was recorded for all the traits except days to $50 \%$ flowering $(15.017 \%)$ and number of seeds of siliqua (16.987) which manifested moderate $\mathrm{h}_{\mathrm{n}}^{2}$. In general, the observed low heritability is unexpected because the local unselected materials were used as lines. This could be attributed to the inability of the testers to efficiently discriminate the lines. Also the poor adaptation of local materials to the test conditions to express their useful traits could have limited the expression of favorable constellation of traits and hence the variability.

The low to moderate estimates of narrow sense heritability $\left(h^{2} n\right)$ for the characters studied further substantiated the insignificant role of additive genes in governing these traits. Similar observations were also reported by Jindal and Labana (1986),Gupta (1991) and Tripathi (2002). Since expression of nonadditive genetic component and its exploitation stands from heterozygosity therefore maintenance of heterozygosity or it restoration at the end of breeding programme is of paramount importance. As this type of gene action is non-fixable in nature, simple selection methods may not be effective. Therefore, the appropriate breeding methodologies could be suggested as heterosis breeding or biparental mating followed by recurrent selection or diallel selective mating as these are likely to be more rewarding Jensen (1970) Rosielle and Frey (1975). 
Contribution of lines, tester and line vs. tester

The knowledge of per cent contribution of lines, testers and their interactions; towards the expression of yield traits; gives an idea about maternal and paternal effects on the expression of concerned traits as well as the idea of relative importance of nature and magnitude of genetic variability present in material studied. Fixable component of genetic variation is reflected by the contribution of lines and testers while nonfixable effects are shown by line $\times$ tester interaction component. The proportion of contribution of lines, testers and line $\times$ tester for 12 characters in yellow sarsonare presented and discussed in (Table 7). In the present study the proportional contribution of line $\times$ tester was observed to be greater than those of lines and testers for all characters barring days to $50 \%$ flowering, plant height and number of seeds per siliqua, for which maximum contribution was made by testers. For length of siliqua per cent contribution of line was higher than that of tester and line $x$ tester. Above findings are also sustained by relatively higher magnitude of SCA variance than GCA variance for the characters studied. Similar findings were also reported by Channa, Tian et al., (2018).

\section{Heterosis}

The desirable SCA effect may not be of practical importance until and unless per se performance of these combinations are compared to that of respective better parent (BP) and with standard variety (SV). The extents of heterotic effects conceived in the pool of materials available influence the success of a hybrid breeding programme. Significant levels of heterosis with respect to seed yield and its components have been observed in the current study which showed greater advantage in adverse environmental conditions Goswami, Thakral et al.,(2004). In pursuance to this objective, estimates of heterobeltiotic response as well as responses relative to standard variety (Pant Sweta) were computed for all the traits in different cross combinations. A cursory view on the heterotic estimate in the pool of material studied revealed that frequency of crosses manifesting heterosis in desired direction were few in number for 8 out of the 12 characters including seed yield and oil content. A reference to the magnitude of heterosis and frequency of crosses showing heterosis for short statured plants and earliness of flowering and maturity are very limited. For days to maturity three crosses displayed desired heterobeltiotic response ranging from -2.74 to $-4.36 \%$. Similarly for earliness of flowering desired BP heterosis $-5.26 \%$ to $6.98 \%$. It is reported that heterosis for this trait is quantitatively photosensitive (Singh, 1973), which flowers only when total photoperiodic requirement is met. In the similar fashion, 18 crosses each for number of primary branches per plant and length of main raceme, 14 for siliqua on main raceme, 2 for siliqua length, 1 for number of seeds per siliqua, seven for 1000-seed weight manifested significant heterosis over BP in desirable direction. Consonantly, 36, 42, 39, 7, 4 and 9 crosses registered heterosis over $\mathrm{SV}$ for aforementioned traits in that order. A perusal of per cent heterotic response and frequency of heterotic crosses for primary branches per plant, length of main raceme and siliquae on main raceme was comparatively more than for other characters. About $41 \%$ of the crosses manifested heterosis for primary branches per plant as well as for length of main raceme and $32 \%$ crosses for siliquae on main raceme. For these characters the level of heterosis was also of high magnitude. Heterosis of similar magnitude has been reported by Khulbe, Pant et al., (1998) and Singh, Gupta et al., (2003) for number of primary branches, Asthana and Pandey (1977) for siliqua on main raceme andKhulbe, Pant 
et al., (1998) for length of main raceme. For seed yield, The magnitude of better parent heterosis among the crosses ranged from 53.30 (NDYS-117×YSH-401) to 81.69 (PYSC-11-46 $\times$ B-9). Out of 44 crosses, 12 crosses manifested significant positive heterosis in desired direction. In the similar way the range of economic heterosis for seed yield per plant varied from -44.57 (NDYS$117 \times$ YSH-401) to 44.54 (PYSC-11-36×YSH$401)$. Out of 44 crosses, only eight crosses manifested heterosis over SV in positive direction. Of these seven crosses displayed heterosis over both BP as well as SV. Higher magnitude of heterotic response for seed yield in rapeseed was also reported by Varshnev and Rao (1997) and Bhajan and Tripathi (1999). Although the level of significant positive heterosis manifested for oil content was of low magnitude. Nevertheless desirable heterosis was shown by four crosses over BP, of which two crosses also exhibited heterosis over SV. The general pattern of low heterosis for oil content as observed from the present study is in concord with the earlier reports Prajapati, Patel et al., (2007). This could be attributed to the fact that, physiologically, as specific metabolic system of plant species sets an absolute limit to the directional portioning of available photosynthates into more valuable compounds like oil at the cost of carbohydrates Bhatia and Mitra (1992).

Table.1 Parental Source/Pedigree and characteristics of the experimental material

\begin{tabular}{|c|c|c|c|}
\hline S. No. & Name of parents & Place of collection/pedigree & $\begin{array}{l}\text { Characteristics (siliqua type and bearing } \\
\text { pattern) }\end{array}$ \\
\hline 1 & PYSC-11-3 & East Uttar Pradesh & Multilocular siliqua, with upright bearing \\
\hline 2 & PYSC-11-31 & Deoria Uttar Pradesh & Multilocular siliqua, with droopy bearing \\
\hline 3 & PYSC-11-36 & Deoria Uttar Pradesh & Multilocular siliqua, with upright bearing \\
\hline 4 & PYSC-11-44 & Uttarakhand Hills & $\begin{array}{l}\text { multilocular siliqua with Upright bearing, } \\
\text { lax, }\end{array}$ \\
\hline 5 & PYSC-11-46 & Uttarakhand Hills & Multilocular siliqua, with upright bearing \\
\hline 6 & PYSC-13-1 & Champaran, Bihar & Multilocular siliqua, with upright bearing \\
\hline 7 & PYSC-13-12 & Chapra, Bihar & $\begin{array}{l}\text { Drum shaped multilocular siliqua, with } \\
\text { upright bearing }\end{array}$ \\
\hline 8 & PYSC-13-14-2 & Motihari, Bihar & Multilocular siliqua, with upright bearing \\
\hline 9 & IC-338742 & Uttarakhand Hills & Bilocular siliqua with upright bearing \\
\hline 10 & NDYS-117 & Selection from eastern U.P. & Multilocular siliqua with upright bearing \\
\hline 11 & PYSC-12-1 & Uttarakhand Hills & $\begin{array}{l}\text { Bilocular siliqua, upright bearing, creamy } \\
\text { colour flowers }\end{array}$ \\
\hline 12 & YSH-401 & $\begin{array}{l}\text { Seletion from germplasm of } \\
\text { Sunderban }\end{array}$ & Multilocular siliqua with upright bearing \\
\hline 13 & B-9 (Benoy-9) & $\begin{array}{l}\text { Pureline selection from } \\
\text { Karimganj, Assam }\end{array}$ & Bilocular siliqua with upright bearing \\
\hline 14 & PPS-1 & $\begin{array}{lll}\begin{array}{l}\text { Selection } \\
\text { germplasm }\end{array} & \text { from } & \text { local } \\
\end{array}$ & Multilocular siliqua with pendant bearing \\
\hline 15 & Pant Sweta & PYS-841 × PYS-7 & Multilocular siliqua with upright bearing \\
\hline
\end{tabular}


Table. 2 Analysis of variance for 12 characters in line $\times$ tester mating design including parents in yellow sarson

\begin{tabular}{|c|c|c|c|c|c|c|c|c|c|}
\hline $\begin{array}{l}\text { Mean Squares Source } \\
\text { of Variation }\end{array}$ & Replication & Treatment & Parents & Parents vs. Crosses & Crosses & Line & Tester & $\mathbf{L} \times \mathbf{T}$ & Error \\
\hline DF & 2 & 58 & 14 & 1 & 43 & 10 & 3 & 30 & 116 \\
\hline Days to $50 \%$ flowering & 135.61 & $30.46 * *$ & $28.76 * *$ & $34.58 * *$ & $30.91 * *$ & 10.51 & $322.27 * *$ & $8.58 * *$ & 1.44 \\
\hline Days to maturity & 7.19 & $97.16 * *$ & $108.52 * *$ & $70.06 * *$ & $94.09 * *$ & 43.71 & $352.80 * *$ & $85.01 * *$ & 1.55 \\
\hline Plant height (cm) & 4.26 & $358.38 * *$ & $272.91 * *$ & $1243.25 * *$ & $365.60 * *$ & $532.49 * *$ & $1833.36 * *$ & $163.19 * *$ & 6.29 \\
\hline $\begin{array}{l}\text { Number of primary } \\
\text { branches per plant }\end{array}$ & 3.69 & $5.70 * *$ & $6.44 * *$ & 69.53 & $3.98 * *$ & $7.71 * *$ & 4.2 & $2.71 * *$ & 0.86 \\
\hline Length of main raceme & 12.5 & $175.17 * *$ & $227.51 * *$ & $1934.24 * *$ & $117.26 * *$ & 92.92 & $644.12 * *$ & $72.64 * *$ & 7.84 \\
\hline $\begin{array}{l}\text { Number of siliquae on } \\
\text { main raceme }\end{array}$ & 10.8 & $215.87 * *$ & $243.49 * *$ & $548.32 * *$ & $199.15 * *$ & 191.84 & $898.99 * *$ & $131.60 * *$ & 7.34 \\
\hline Siliqua density & 0.004 & $0.04 * *$ & $0.04 * *$ & 0.002 & $0.03 * *$ & $0.05^{*}$ & $0.11 * *$ & $0.03 * *$ & 0.002 \\
\hline Siliqua length $(\mathrm{cm})$ & 0.05 & $1.15^{* *}$ & $0.59 * *$ & $7.95 * *$ & $1.18 * *$ & $2.35^{* *}$ & $2.76^{* *}$ & $0.63 * *$ & 0.05 \\
\hline Seeds per siliqua, & 3.96 & $137.41 * *$ & $102.63 * *$ & $740.57 * *$ & $134.70 * *$ & $158.00 * *$ & $1020.00 * *$ & $38.41 * *$ & 2.12 \\
\hline 1000-seed weight $(\mathrm{g})$ & 0.03 & $1.34 * *$ & $1.36^{* *}$ & 0.0001 & 1.36 & 1.22 & $3.48 *$ & $1.20 * *$ & 0.03 \\
\hline Seed yield per plant (g) & 21.19 & $8.97 * *$ & $4.41 * *$ & $48.79 * *$ & $9.54 * *$ & 14.88 & 3.99 & $8.31 * *$ & 0.91 \\
\hline Oil content $(\%)$ & 6.56 & $1.57 * *$ & $2.32 * *$ & 0.41 & $1.35^{* *}$ & $2.08 *$ & 1.84 & $1.06^{* *}$ & 0.23 \\
\hline
\end{tabular}

$*$ and $* *$, significant at $5 \%$ and $1 \%$ probability level respectively 
Table.3 GCA effects of parents for different characters in yellow sarson

\begin{tabular}{|c|c|c|c|c|c|c|c|c|c|c|c|c|c|}
\hline S. No. & Parents & DF & DM & PH & NPB & LMR & SMR & SD & SL & NSS & TW & SY & OC \\
\hline 1 & PYSC-11-3 & $1.93 * *$ & $-1.40 * *$ & 0.17 & $-1.27 * *$ & 1.03 & $-1.71 *$ & $-0.05^{*}$ & $0.16^{* *}$ & -0.02 & $0.57 * *$ & $1.33 * *$ & 0.16 \\
\hline 2 & PYSC-11-31 & 0.18 & $-2.56 * *$ & $10.74 * *$ & 0.21 & $4.51 * *$ & $4.34 * *$ & 0.03 & $0.33 * *$ & $3.18 * *$ & 0.009 & 0.28 & 0.09 \\
\hline 3 & PYSC-11-36 & $0.93 * *$ & $-1.23 * *$ & $11.77 * *$ & $0.78 * *$ & $4.40 * *$ & $6.72 * *$ & $0.08 * *$ & $-0.45 * *$ & $-1.29 * *$ & -0.09 & $1.77 * *$ & -0.16 \\
\hline 4 & PYSC-11-44 & -0.23 & -0.15 & $-5.79 * *$ & $0.82 * *$ & -0.96 & $5.73 * *$ & $0.14 * *$ & $-0.37 * *$ & 0.74 & $-0.13 * *$ & $1.13 * *$ & 0.09 \\
\hline 5 & PYSC-11-46 & $-0.82 *$ & 0.09 & 1.36 & $-1.46 * *$ & $-1.94 *$ & 0.008 & 0.006 & $0.53 * *$ & $7.13 * *$ & -0.08 & $0.56^{*}$ & -0.01 \\
\hline 6 & PYSC-13-1 & 0.43 & $4.01 * *$ & 0.58 & 0.39 & $2.09 *$ & 0.39 & -0.02 & $-0.59 * *$ & -0.15 & $0.44 * *$ & -0.12 & $0.34 *$ \\
\hline 7 & PYSC-13-12 & -0.57 & $-1.65^{* *}$ & $-1.41 *$ & 0.01 & 0.73 & -0.14 & -0.003 & $-0.63 * *$ & -0.39 & $0.21 * *$ & $-1.78 * *$ & -0.17 \\
\hline 8 & PYSC-13-14-2 & $-0.98 * *$ & $-0.98 * *$ & $-7.71 * *$ & 0.44 & -1.42 & $-4.50 * *$ & $-0.09 * *$ & $0.14 * *$ & $0.84 * *$ & $-0.52 * *$ & $-0.73 * *$ & 0.15 \\
\hline 9 & IC-338742 & $-0.82 *$ & 0.35 & $3.04 * *$ & $-0.57 *$ & $-3.72 * *$ & $-3.13 * *$ & -0.008 & $0.57 * *$ & $-6.52 * *$ & $-0.22 * *$ & $-0.55^{*}$ & $-1.06 * *$ \\
\hline 10 & NDYS-117 & $0.77 *$ & $1.52 * *$ & $-7.42 * *$ & $0.79 * *$ & $-2.41 * *$ & $-3.53 * *$ & $-0.04 *$ & $0.34 * *$ & $1.31 * *$ & $-0.30 * *$ & $-0.88 * *$ & -0.03 \\
\hline 11 & PYSC-12-1 & $-0.82 *$ & $2.01 * *$ & $-5.32 * *$ & -0.22 & $-2.32 * *$ & $-4.17 * *$ & $-0.06 * *$ & -0.02 & $-4.84 * *$ & $0.13 * *$ & $-1.02 * *$ & $0.60 * *$ \\
\hline \multicolumn{2}{|r|}{ SE(gi) } & 0.346 & 0.346 & 0.36 & 0.72 & 0.27 & 0.81 & 0.78 & 0.02 & 0.06 & 0.42 & 0.05 & 0.28 \\
\hline \multicolumn{2}{|r|}{ SE(gi-gj) } & 0.490 & 0.490 & 0.51 & 1.02 & 0.38 & 1.14 & 1.11 & 0.02 & 0.09 & 0.59 & 0.03 & 0.39 \\
\hline 12 & B-9 & $-4.49 * *$ & $-3.25 * *$ & $-2.21 * *$ & $0.50 * *$ & $-2.10 * *$ & $-2.32 * *$ & $-0.02 *$ & $0.14 * *$ & $-8.29 * *$ & $-0.33 * *$ & $0.41^{*}$ & $0.32 * *$ \\
\hline 13 & YSH-401 & $2.68 * *$ & $4.30 * *$ & $10.03 * *$ & -0.22 & $3.69 * *$ & $5.05^{* *}$ & $0.06 * *$ & $-0.13 * *$ & $3.49 * *$ & $0.22 * *$ & $-0.38 *$ & -0.07 \\
\hline 14 & PPS-1 & $0.59 * *$ & $-1.64 * *$ & -0.03 & 0.002 & $3.64 * *$ & $3.47 * *$ & $0.03 * *$ & $-0.33 * *$ & $2.00 * *$ & $0.33 * *$ & 0.14 & $-0.24 * *$ \\
\hline 15 & Pant Sweta & $1.23 * *$ & $2.02 * *$ & $-7.82 * *$ & -0.29 & $-5.23 * *$ & $-6.21 * *$ & $-0.07 * *$ & $0.33 * *$ & $2.80 * *$ & $-0.22 * *$ & -0.17 & -0.02 \\
\hline \multicolumn{2}{|r|}{ SE(gi) \pm} & 0.21 & 0.21 & 0.22 & 0.44 & 0.16 & 0.49 & 0.47 & 0.009 & 0.04 & 0.25 & 0.03 & 0.17 \\
\hline \multicolumn{2}{|r|}{ SE(gi-gj) \pm} & 0.29 & 0.29 & 0.31 & 0.62 & 0.23 & 0.69 & 0.67 & 0.013 & 0.05 & 0.36 & 0.04 & 0.23 \\
\hline
\end{tabular}

* and **, significant at $5 \%$ and $1 \%$ probability level respectively

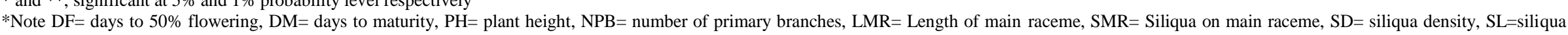
length, NSS = number of seeds per siliqua, TW= Test weight, $\mathrm{SY}=$ seed yield/plant, $\mathrm{OC}=$ oil content 
Table.4 Promising donors for different characters identified based on their GCA effects

\begin{tabular}{|c|c|c|c|}
\hline \multirow[t]{2}{*}{ S. No. } & \multirow[t]{2}{*}{ Characters } & \multicolumn{2}{|l|}{ Promising Combiners } \\
\hline & & Lines/Testers & Numbers \\
\hline 1 & Days to $50 \%$ flowering & $\begin{array}{l}\text { B-9, PYSC-11-46, PYSC-13-14-2, PYSC-12-1, } \\
\text { IC-338742 }\end{array}$ & 5 \\
\hline 2 & Days to maturity & $\begin{array}{l}\text { PYSC-11-3, PYSC-11-31, PYSC-11-36, PYSC- } \\
\text { 13-12, PYSC-13-14-2, B-9 }\end{array}$ & 6 \\
\hline 3 & Plant height $(\mathrm{cm})$ & $\begin{array}{l}\text { PYSC-11-44, PYSC-13-12, PYSC-13-14-2, } \\
\text { NDYS-117, PYSC-12-1, B-9, Pant Sweta }\end{array}$ & 7 \\
\hline 4 & $\begin{array}{l}\text { Number of primary branches per } \\
\text { plant }\end{array}$ & PYSC-11-36, PYSC-11-44, NDYS-117, B-9 & 4 \\
\hline 5 & Length of main raceme & $\begin{array}{l}\text { PYSC-11-31, PYSC-11-36, PYSC-13-1, YSH- } \\
\text { 401, PPS-1 }\end{array}$ & 5 \\
\hline 6 & Number of siliquae on main raceme & $\begin{array}{l}\text { PYSC-11-31, PYSC-11-36, PYSC-11-44, YSH- } \\
\text { 401, PPS-1 }\end{array}$ & 5 \\
\hline 7 & Siliqua density & PYSC-11-31, PYSC-11-36, YSH-401, PPS-1 & 4 \\
\hline 8 & Siliqua length $(\mathrm{cm})$ & $\begin{array}{l}\text { PYSC-11-3, PYSC-11-31, PYSC-11-46, PYSC- } \\
\text { 13-14-2, IC-338742, NDYS-117, B-9, Pant Sweta }\end{array}$ & 7 \\
\hline 9 & Seeds per siliqua, & $\begin{array}{l}\text { PYSC-11-31, PYSC-11-44, PYSC-11-46, PYSC- } \\
\text { 13-14-2, NDYS-117, YSH-401, PPS-1, Pant } \\
\text { Sweta }\end{array}$ & 8 \\
\hline 10 & 1000-seed weight $(\mathrm{g})$ & $\begin{array}{l}\text { PYSC-11-3, PYSC-13-1, PYSC-13-12, PYSC- } \\
\text { 12-1, YSH-401, PPS-1 }\end{array}$ & 6 \\
\hline 11 & Seed yield per plant $(\mathrm{g})$ & $\begin{array}{l}\text { PYSC-11-3, PYSC-11-36, PYSC-11-44, PYSC- } \\
\text { 11-46, B-9 }\end{array}$ & 5 \\
\hline 12 & Oil content $(\%)$ & PYSC-12-1, PYSC-13-1, B-9 & 3 \\
\hline
\end{tabular}

Table.5 Trait wise superior cross combinations for different trait in yellow sarson

\begin{tabular}{|c|c|c|c|}
\hline S. No. & Characters & Crosses & No. \\
\hline 1 & Days to $50 \%$ flowering & $\begin{array}{l}\text { PYSC-11-31× B-9, PYSC-11-36×YSH-401, PYSC- } \\
\text { 11-44×YSH-401, PYSC-13-12×PPS-1, PYSC-13- } \\
\text { 14-2×Pant Sweta, IC-338742×PPS-1 }\end{array}$ & 7 \\
\hline 2 & Days to maturity & 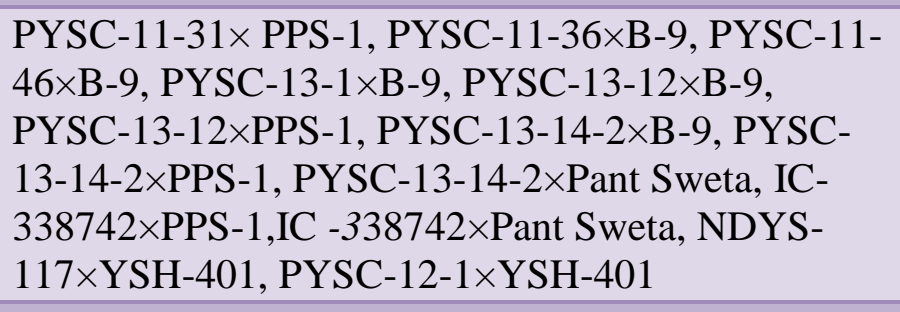 & 13 \\
\hline 3 & Plant height $(\mathrm{cm})$ & $\begin{array}{l}\text { PYSC-11-3×YSH-401, PYSC-11-3×Pant Sweta, } \\
\text { PYSC-11-31×Pant Sweta, PYSC-11-36×B-9, PYSC- } \\
\text { 11-44×B-9, PYSC-11-44×YSH-401, PYSC-11- } \\
\text { 44×PPS-1,PYSC-11-46×B-9, PYSC-11-46×Pant } \\
\text { Sweta, PYSC-13-12×YSH-401, PYSC-13-14- }\end{array}$ & 16 \\
\hline
\end{tabular}




\begin{tabular}{|c|c|c|c|}
\hline & & $\begin{array}{l}\text { 2×YSH-401, PYSC-12-1×B-9, IC-338742×PPS-1, } \\
\text { NDYS-117×B-9 }\end{array}$ & \\
\hline 4 & Number of primary branches per plant & $\begin{array}{l}\text { PYSC-11-3×PPS-1, PYSC-11-36×Pant Sweta, } \\
\text { PYSC-11-46× B-9, IC-338742×Pant Sweta }\end{array}$ & 4 \\
\hline 5 & Length of main raceme & $\begin{array}{l}\text { PYSC-11-3×PPS-1, PYSC-11-44×Pant Sweta, } \\
\text { PYSC-11-46× YSH-401, PYSC-13-1×B-9, PYSC- } \\
\text { 13-14-2×Pant Sweta, IC-338742×Pant Sweta, } \\
\text { PYSC-12-1×YSH-401,PYSC-12-1×PPS-1 }\end{array}$ & 8 \\
\hline 6 & Number of siliquae on main raceme & $\begin{array}{l}\text { PYSC-11-3×PPS-1, PYSC-11-31×YSH-401, PYSC- } \\
\text { 11-31×PPS-1, PYSC-11-36×PPS-1, PYSC-11- } \\
\text { 44×PPS-1,PYSC-11-44×Pant Sweta, PYSC-11-46× } \\
\text { YSH-401, PYSC-13-1×B-9, PYSC-13-14-2×YSH- } \\
\text { 401, PYSC-13-14-2×Pant Sweta,IC-338742×B-9, } \\
\text { PYSC-12-1×PPS-1 }\end{array}$ & 12 \\
\hline 7 & Siliqua density & $\begin{array}{l}\text { PYSC-11-3×PPS-1, PYSC-11-31×PPS-1, PYSC-11- } \\
\text { 36×B-9, PYSC-11-44×Pnt Sweta, PYSC-11- } \\
\text { 46×YSH-401, PYSC-13-1×B-9, PYSC-13-14- } \\
\text { 2YSH-401, IC-338742×B-9, IC-338742×YSH-401, } \\
\text { PYSC-12-1×PPS-1, PYSC-12-1×Pant Sweta }\end{array}$ & 11 \\
\hline 8 & Siliqua length $(\mathrm{cm})$ & $\begin{array}{l}\text { PYSC-11-31×Pant Sweta, PYSC-11-36×YSH-401, } \\
\text { PYSC-11-44×PPS-1, PYSC-11-46×B-9, PYSC-13- } \\
\text { 1×YSH-401, PYSC-13-14-2×PPS-1, IC- } \\
338742 \times \text { PPS-1, IC-338742×Pant Sweta, NDYS- } \\
117 \times B-9 \text {, NDYS-117×PPS-1, PYSC-12-1×PPS-1 }\end{array}$ & 11 \\
\hline 9 & Seeds per siliqua, & 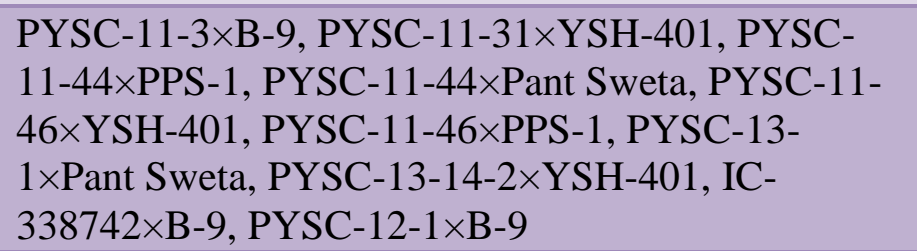 & 10 \\
\hline 10 & 1000-seed weight $(\mathrm{g})$ & $\begin{array}{l}\text { PYSC-11-3×PPS-1, PYSC-11-31×Pant Sweta, } \\
\text { PYSC-11-36×B-9, PYSC-11-36×PPS-1, PYSC-11- } \\
\text { 44×YSH-401, PYSC-11-44×Pant Sweta, PYSC-11- } \\
\text { 46×B-9, PYSC-11-46×PPS-1, PYSC-13-1×PPS-1, } \\
\text { PYSC-13-12×PPS-1, PYSC-13-12×Pant Sweta, } \\
\text { PYSC-13-14-2×B-9, IC-338742×B-9, NDYS- } \\
\text { 117×B-9, NDYS-117×Pant Sweta, PYSC-12-1×B-9 }\end{array}$ & 15 \\
\hline 11 & Seed yield per plant (g) & $\begin{array}{l}\text { PYSC-11-31×YSH-401, PYSC-11-31×Pant Sweta, } \\
\text { PYSC-11-36×YSH-401, PYSC-11-44×PPS-1, } \\
\text { PYSC-11-44×Pant Sweta, PYSC-11-46×B-9, PYSC- } \\
\text { 11-46×YSH-401, PYSC-13-1×YSH-401, IC- } \\
\text { 338742×PPS-1, NDYS-117×PPS-1, NDYS- } \\
\text { 117×Pant Sweta }\end{array}$ & 11 \\
\hline 12 & Oil content $(\%)$ & $\begin{array}{l}\text { PYSC-11-46×Pant Sweta, PYSC-13-1×Pant Sweta, } \\
\text { PYSC-13-12×PPS-1, IC-338742×YSH-401, NDYS- } \\
117 \times \text { Pant Sweta, PYSC-12-1×PPS-1 }\end{array}$ & 7 \\
\hline
\end{tabular}


Table.6 Estimates of components of variance, degree of dominance, additive and dominance components and heritability in narrow sense for 12 different characters in yellow sarson

\begin{tabular}{|l|c|c|c|c|c|c|c|c|}
\hline \multirow{2}{*}{ Characters } & \multicolumn{9}{|c|}{ Components of variance } \\
\cline { 2 - 10 } & $\boldsymbol{\sigma}^{\mathbf{2}} \mathbf{g c a}$ & $\boldsymbol{\sigma}^{\mathbf{2}} \mathbf{s c a}$ & $\boldsymbol{\sigma}^{\mathbf{2}} \mathbf{g c a} / \mathbf{\sigma}^{\mathbf{2}} \mathbf{s c a}$ & $\boldsymbol{\sigma}^{\mathbf{2}} \mathbf{D}$ & $\boldsymbol{\sigma}^{\mathbf{2}} \mathbf{H}$ & $\mathbf{( \boldsymbol { \sigma } ^ { \mathbf { H } } \mathbf { H } \boldsymbol { \sigma } ^ { \mathbf { 2 } } \mathbf { D } ) ^ { \mathbf { 1 } / \mathbf { 2 } }}$ & $\mathbf{h}^{\mathbf{2}}(\mathbf{n})$ & $\mathbf{h}^{\mathbf{2}}(\mathbf{n}) \%$ \\
\hline DF & 0.337 & 2.378 & 0.142 & 0.675 & 2.378 & 1.877 & 0.15 & 15.017 \\
\hline DM & 0.137 & 27.818 & 0.005 & 0.274 & 27.818 & 10.072 & 0.009 & 0.925 \\
\hline PH & 3.057 & 52.301 & 0.058 & 6.114 & 52.301 & 2.925 & 0.094 & 9.449 \\
\hline NPB & 0.019 & 0.615 & 0.031 & 0.038 & 0.615 & 4.011 & 0.025 & 2.51 \\
\hline LMR & 0.673 & 21.599 & 0.031 & 1.347 & 21.599 & 4.005 & 0.044 & 4.375 \\
\hline SMR & 1.02 & 41.42 & 0.025 & 2.04 & 41.42 & 4.505 & 0.04 & 4.011 \\
\hline SD & 0.0002 & 0.008 & 0.024 & 0.0004 & 0.008 & 4.591 & 0.036 & 3.644 \\
\hline SL & 0.008 & 0.193 & 0.043 & 0.017 & 0.193 & 3.409 & 0.064 & 6.397 \\
\hline NSS & 1.454 & 12.095 & 0.12 & 2.909 & 12.095 & 2.039 & 0.17 & 16.987 \\
\hline TW & & & & & & & & \\
\hline SY & 0.002 & 0.389 & 0.006 & 0.005 & 0.389 & 8.866 & 0.012 & 1.167 \\
\hline OC & 0.018 & 2.468 & 0.007 & 0.037 & 2.468 & 8.173 & 0.011 & 1.085 \\
\hline
\end{tabular}

Table.7 Proportion contribution of lines, tester and interaction to total variance for 12 characters in yellow sarson

\begin{tabular}{|l|l|l|l|}
\hline Characters & Lines & Testers & Line $\times$ Tester \\
\hline Days to 50\% flowering & 7.91 & 72.73 & 19.36 \\
\hline Days to maturity & 10.8 & 26.16 & 63.04 \\
\hline Plant height (cm) & 33.87 & 34.99 & 31.14 \\
\hline Number of primary branches per plant & 45.06 & 7.36 & 47.57 \\
\hline Length of main raceme & 18.43 & 38.33 & 43.23 \\
\hline Number of siliquae on main raceme & 22.4 & 31.49 & 46.1 \\
\hline Siliqua density & 32.31 & 20.17 & 47.52 \\
\hline Siliqua length (cm) & 46.47 & 16.36 & 37.17 \\
\hline Seeds per siliqua, & 27.28 & 52.83 & 19.89 \\
\hline 1000-seed weight (g) & 20.79 & 17.84 & 61.37 \\
\hline Seed yield per plant (g) & 36.3 & 2.88 & 60.82 \\
\hline Oil content (\%) & 35.74 & 9.46 & 54.8 \\
\hline & & & \\
\hline
\end{tabular}


Table.8 Prospective cross combinations based on per se performance and desirable SCA effects seed yield per plant and oil content (per cent) and suggesting breeding strategy

\begin{tabular}{|c|c|c|c|c|c|c|c|}
\hline \multirow{2}{*}{$\begin{array}{c}\text { Cross } \\
\text { combinations }\end{array}$} & \multirow{2}{*}{$\begin{array}{c}\text { Perse } \\
\text { performance } \\
(\mathrm{g} / \text { plant })\end{array}$} & \multirow{2}{*}{$\begin{array}{c}\text { SCA } \\
\text { effects }\end{array}$} & \multicolumn{2}{|c|}{ Heterosis (\%) } & \multirow{2}{*}{$\begin{array}{c}\text { GCA } \\
\text { effect of } \\
\text { combining } \\
\text { parent }\end{array}$} & \multirow{2}{*}{$\begin{array}{c}\text { Other } \\
\text { characters } \\
\text { with } \\
\text { significant } \\
\text { SCA effects }\end{array}$} & \multirow{2}{*}{$\begin{array}{c}\text { Suggested } \\
\text { breeding method }\end{array}$} \\
\hline & & & BP & SV & & & \\
\hline \multicolumn{8}{|c|}{ Seed Yield (g/plant) } \\
\hline $\begin{array}{l}\text { PYSC-11- } \\
\text { 36×YSH-401 }\end{array}$ & 11.44 & $2.063 * *$ & $21.70^{* *}$ & $44.44 * *$ & $\mathrm{H} \times \mathrm{L}$ & $\mathrm{DF}, \mathrm{SL}$ & $\begin{array}{l}\text { Heterosis } \\
\text { breeding / mass } \\
\text { selection with } \\
\text { concurrent } \\
\text { random mating }\end{array}$ \\
\hline $\begin{array}{l}\text { PYSC-11- } \\
46 \times B-9\end{array}$ & 10.72 & $1.767 * *$ & $81.69^{* *}$ & $35.35^{* *}$ & $\mathrm{H} \times \mathrm{H}$ & $\begin{array}{l}\text { DM, NPB, } \\
\text { SL, TW }\end{array}$ & $\begin{array}{l}\text { Heterosis } \\
\text { breeding } \\
\text { conventional } \\
\text { breeding methods } \\
\text { with selection } \\
\text { pressure on PH } \\
\text { NSS, PB, S/P } \\
\text { and OC }\end{array}$ \\
\hline \multicolumn{8}{|c|}{ Oil content (per cent) } \\
\hline $\begin{array}{l}\text { PYSC-12- } \\
1 \times B-9\end{array}$ & 44.967 & 0.354 & $2.32 * *$ & $1.89^{*}$ & $\mathrm{H} \times \mathrm{H}$ & $\begin{array}{l}\text { TW, NSS, } \\
\text { PH }\end{array}$ & $\begin{array}{l}\text { Heterosis } \\
\text { breeding } \\
\text { conventional } \\
\text { breeding methods } \\
\text { with selection } \\
\text { pressure on PH } \\
\text { NSS, TW }\end{array}$ \\
\hline $\begin{array}{l}\text { PYSC-12- } \\
\text { 1×PPS-1 }\end{array}$ & 44.833 & 0.788 & $2.00^{*}$ & $1.59^{*}$ & $\mathrm{H} \times \mathrm{L}$ & $\begin{array}{l}\text { LMR, SMR, } \\
\text { SD, SL }\end{array}$ & $\begin{array}{l}\text { Heterosis } \\
\text { breeding / with } \\
\text { concurrent } \\
\text { random mating }\end{array}$ \\
\hline
\end{tabular}

Considering the overall results on heterosis for seed yield and oil content vis-à-visper se performance and SCA effects of crosses in conjugation with GCA status of the parents promising crosses have been identified (Table 8). Besides, this table also presents significant SCA effects of the related traits and suggested breeding methodology for genetic improvement. Based on these argument three potential crosses could be identified for seed yield per plant and two for oil content. GCA status of both the parents of best heterotic cross (PYSC-11-46×B-9) was high. Thus, this cross is amenable for improvement through conventional breeding procedures with selection pressure days to $50 \%$ flowering, days to maturity, siliqua length, number of seeds per siliqua and oil content. The other two promising crosses for seed yield combined parents with differing GCA status. 
Thus, it is obvious that a good cross combination is not always the result of high $\times$ high GCA parents instead it can also result from high $\times$ Average or high $\times$ low GCA parents. High GCA status of one of the parent and average/poor of the other in heterotic crosses showed that additive gene effects of good general combiner and epistatic effects of poor combiner acted in a complementary manner leading to high expression of the traits. Such crosses are amenable to improvement through biparental mating and heterosis breeding. Similarly for oil content one of the cross combined high $\times$ high and other high $\times$ low GCA parents. Though both these crosses displayed significant heterosis over BP as well as over SV, albeit of low magnitude. The SCA effect of the marked heterotic cross, PYSC-12-1 × B-9, was nonsignificant indicating thereby the poor specific combining ability of this cross. The overall results elucidated prevalence of nonadditive genetic variance for all the characters exhibiting the advantage of heterozygosity for desired expression of the traits. Four lines could be identified as high general combiner for seed yield and three to five component traits indicating their greater utility in the yellow sarson improvement. Promising crosses identified for seed yield and oil content can be exploited using appropriate methodology suggested.

\section{Acknowledgement}

The Author would like to thank ICAR and University Department of genetics and plant breeding, GBPUAT, Pantnagar for funding the research.

\section{References}

Asthana, A. and V. Pandey (1977). "Combining ability and rank correlations in a diallel cross of Indian mustard (Brassica juncea)." Experimental Agriculture, 13(1): 71-79.
Bhajan, R. and A. Tripathi (1999). "Choice of parents for seed yield heterosis in Toria (Brassica campestris L.)." Cruciferae Newsletter: 81-82.

Bhatia, C. and R. Mitra (1992). Bioenergetic limitations to breeding better Brassicas. Chapter 5. In "Breeding oilseed Brassicas" (Labana, KS, Banga, SS, Banga, SK, eds.), Narosa Publishing House, New Delhi.

Channa, S. A., Tian, H., Mohammed, M. I., Zhang, R., Faisal, S., Guo, Y., Hu, S. (2018). Heterosis and combining ability analysis in Chinese semi-winterx exotic accessions of rapeseed (Brassica napus L.). Euphytica, 214(8), 134.

Chaudhari, N., Patel, R., Gami, R., and Shah, S. (2015). Study of combining ability and heterosis for seed yield and seed quality traits in rapeseed [Brassica rapa 1.].

Dar, Z. A., Wani, S. A., and Wani, M. A. (2016). Heterosis and combining ability analysis for seed yield and its attributes in Brassica rapa ssp. brown sarson. Journal of Oilseed Brassica, 1(1), 21-28.

Dhillon, S. S., Labana, K. S., and Banga, S. K. (1990). Studies on heterosis and combining ability in Indian mustard (Brassica juncea (L.) Coss). Journal of Research, Punjab Agricultural University, 27(1), 1-8.

Goswami, P.K., Thakral, N.K., Behl, R.K., K. Ramesh (2004). "Heterosis breeding in Indian mustard (Brassica juncea L. Czern \& Coss.)." Brassica6(1): 47-51.

Gupta, P., Chaudhary, H. B. and Lal, S. K. (2010). Heterosis and combining ability analysis for yield and its components in Indian mustard (Brassica juncea L. Czern\&Coss). Frontiers of Agriculture in China, 4(3), 299-307.

Hayes, H. K., Immer, F. R., and Smith, D. C. (1955). Methods of plant breeding. McGraw-Hill Book Company, Inc.; New York; London; Toronto.

Jensen, N. F. (1970). A diallel selective mating system for cereal breeding 1. Crop Science, 10(6), 629-635.

Jindal, S. and K. Labana (1986). "Combining ability in a complete diallel cross of Indian mustard." Indian Journal of 
Agricultural Sciences (India).

Kempthorne, O. (1957). An introduction to genetic statistics, John Wiley And Sons, Inc.; New York.

Khulbe, R.K., Pant, D. P., Rawat, R. S (1998) "Heterosis for yield and its components in Indian mustard." Journal of Oilseeds Research15: 227-230.

Pradhan, A. K., Sodhi, Y. S., Mukhopadhyay, A., and Pental, D. (1993). Heterosis breeding in Indian mustard (Brassica juncea L. Czern \& Coss): analysis of component characters contributing to heterosis for yield. Euphytica, 69(3), 219-229.

Prajapati, C. H., Patel, K. M., Patel, M. P., and Pathak, H. C. (2007). Heterosis for seed yield and its components in Indian rapeseed, Brassica campestris var. Yellow Sarson. Journal of Oilseeds Research, 24(2), 309.

Rahman, M. M., Chowdhury, M. A. Z., Hossain, M. G., Amin, M. N., Muktadir, M. A., and Rashid, M. H. (2011). Gene action for seed yield and yield contributing characters in turnip rape (Brassica rapa L.). J. Expt. Biosci, 2(2), 67-76.

Rosielle, A. and K. J. Frey (1975). "Application of Restricted Selection Indices for Grain Yield Improvement in Oats 1." Crop Science15(4): 544-547.

Sachan, S. P., Singh, P., and Singh, S. K. (2004). Genetics of yield components and oil content in yellow seeded Indian mustard.
Farm Science Journal, 13(2), 107-110.

Singh, K. H., Gupta, M. C., Srivastava, K.K ., Kumar, P. K (2003). "Combining ability and heterosis in Indian mustard." JOURNAL OF OILSEEDS RESEARCH.20: 35-39.

Singh, S. P. (1973). "Heterosis and Combining Ability Estimates in Indian Mustard, Brassica juncea (L.) Czern. and Coss. 1." Crop Science13(5): 497-499.

Tomar, A., Singh, M., and Tiwari, L. P. (2018). Combining ability (GCA \& SCA), heterosis and inbreeding depression analysis for quantitative traits in yellow sarson (Brassica rapa var. yellow sarson). Journal of Pharmacognosy and Phytochemistry, 7(3), 2165-2170.

Tripathi, A. K., Bhajan, R., and Kumar, K. (2005). Combining ability analysis for seed yield and its components over environments in Indian colza (Brassica rapa L. var. yellow sarson). The Indian Journal of Genetics and Plant Breeding, 65(2), 137-138.

Tripathi, R. (2002). Genetic studies on intra-and inter specific hybridization in brassica species, Narendra Deva University of Agriculture and Technology; Faizabad.

Varshnev, S. and C. S. Rao (1997). "Combining ability, heterosis and inbreeding depression for yield and yield components in yellow sarson." The Indian Journal of Genetics and Plant Breeding, 57(1): 9197.

\section{How to cite this article:}

Sanchika Snehi, Ram Bhajan, Usha Pant and Singh, N.K. 2019. Combining ability and Heterosis Analysis for Yield and Contributing Traits in Local Germplasm of Yellow Sarson (Brassica rapa var. Yellow Sarson Prain). Int.J.Curr.Microbiol.App.Sci. 8(07): 1120-1133. doi: https://doi.org/10.20546/ijcmas.2019.807.133 